\title{
A MAGYAR FILOZÓFIAI ENCIKLOPÉDIÁRÓL
}

\author{
MEZEI BALÁZS MIHÁLY \\ Vezető szerkesztő
}

Magyar Filozófiai Enciklopédia (MAFE) koncepciója évtizedes. Már az 1990-es években elkezdtem dolgozni egy címszólistán, amely a tervezett enciklopédia alapjául szolgált volna. A finanszírozás hiánya, nem utolsósorban az Akadémiai Kiadó egykori magánosítása sajnos nem kedvezett a folytatásnak. Ezt követően a 200o-es években ismét előkerült az alapgondolat, miután Walter Brugger Filozófiai lexikona szerkesztésemben megjelent, és szép sikert is aratott. Újabb változások, újabb halasztás. A 2010-es évek során, a Magyar Politikai Enciklopédia elkészülte nyomán (melyben magam is szerkesztőként és szerzőként vettem részt), végre megszületett az elhatározás, amely pályázati formát nyert. A Nemzeti Kutatási, Fejlesztési és Innovációs Alap a Tématerületi Kiválósági Program keretében 2019től kezdődően évenként nyújt támogatást a munkánkhoz. A MAFE munkálatait a Budapesti Corvinus Egyetem fogadta be, mely a projektum szellemi és strukturális otthona. Szervezete a vezető szerkesztő mellett a szerkesztőbizottságból, a kuratóriumból és a külső szerzők népes csapatából áll. A tervezett futamidő vége 2025, amit azonban terveink szerint a rövidített angol változat elkészítése követ.

A MAFE címszavai három nagy csoportba oszthatók: szerzői, fogalmi és irányzati címszavak. Mindezeket kiegészíti a kötet készítésével párhuzamosan folyó, összegző bibliográfia. A munka nemcsak könyvalakban jelenik majd meg, hanem külön honlapon is. Mindkét esetben lehetőség nyílik az új kiadásra, a kiegészítésre, a javításra és módosításra. Ekképpen a projektum ötvözi a hagyományos lexikográfiai munkát a digitális kiadványok logikájával. Mindennek megfelelöen a MAFE egyfajta proiectum perpetuum, melyet a következő nemzedék folytathat, korrigálhat, magasabb szintre emelhet.

A MAFE három fő koncepcionális célt követ: (1) Össze kívánja fogni a hazai filozófustársadalmat, annak szakértelmét az egyes szócikkek megírásában fókuszálni. (2) Emléket kíván állítani a magyar nyelvü, magyar indíttatású filozófusok népes csoportjának, melynek tagjai a történelmi Magyarország területéről származnak, és sokan közülük más nyelven, más országban írták meg főbb müveiket, többen közülük az elmúlt évtizedek ismert gondolkodói lettek. (3) Végül, föképpen az angol verzióval, a kortárs nemzetközi tudományos élet számára is világos- 
sá kívánja tenni azt a tematikus, szakértői sokféleséget, azt a sajátos eredetiséget, amelyet a magyar környezetben született bölcseleti gondolkodás létrehozott, illetve a jelen munka szerzőinek munkájában ma is felmutat. Az Encyclopedia of Hungarian Philosophy világossá fogja tenni, hogy a) van magyar filozófia, $b$ ) van tematikusan eredeti magyar gondolkodás, és $c$ ) mindez széles értelemben releváns a mai szellemi világban. A magyar változat célja sem más, mint a hazai, magyar nyelvü bölcselet szolgálata, az oktatás segítése, a filozófia mint tudományos diszciplína megérdemelt helyének megerősítése mindazok közreműködésével, akik a tudományos elkötelezettség mellett tudományos jóakarattal is élnek. Hiszen a filozófia az, ami: évezredes kulturális hagyományaink magas szintü áttekintése, elmélyült ismerete, alkotó továbbgondolása. Röviden: a kultúra magva, melyből hajtások sokasága csírázik ki.

A MAFE ezen túlmenően kutatócsoport, egyetemi munkaközösség is, amely mint ilyen kiadványokkal, értekezleteivel, konferenciáival a hazai és nemzetközi filozófiai élet jellegzetes fókusza kíván lenni. Noha a mai kultúrát mély hasadékok szabdalják, a filozófia mindenkor az efféle különbségeken túlemelkedő, a valóban ésszerü, elmélyült, alapos és körültekintő gondolkodás tere volt és maradt. A MAFE ezen a vonalon halad: világunk minden, olykor igen éles különbsége mellett, ezeket ismerve és értve nem az elmélyítésükön, hanem meghaladásukon dolgozik, egyfajta Aufhebungon, amely a régi és helytelen fordítással szemben nem „megszüntetve-megőriz”, hanem sokkal inkább és elsősorban: felemel. A MAFE mai kultúránk felemelő szellemi vállalkozása kíván lenni. 